\title{
EVALUATION OF PHYSICAL ASPECT OF ISLAMIC RESIDENTIAL CONCEPTS IN THE SHARIA HOUSING PROJECT
}

\author{
Angga Perdana \\ Professional architect, Malang, Indonesia \\ e-mail: angga.perdana.smanti@gmail.com
}

\begin{abstract}
Indonesia is the largest Muslim country in the world. In this country the development of shari'a housing is rapidly increasing, this is due to the demand for the shari'a housing market. To meet the needs of consumers having a house with an ideal Islamic residential concept, some criteria can be applied in developing shari'a housing. Many developers have raised the concept of Islamic housing as a branding of developed housing products, but many housings with that concept have not met all the ideal criteria of the concept of Islamic housing. The ideal Islamic residential concept must meet the ideal criteria including there are two entrances, the separation between the service room and the main room, the separation between the family room and living room for the privacy of the occupants, there are parks and open spaces on the residential lots, there are Islamic-style ornaments or plants, there are shading devices, there are ornaments on the main entrance which are the focal points of the entrance design, natural light and ventilation must be able to reach the entire space, carry the concept of climate response, and meet all applicable housing standards. Based on the evaluation results according to investors and in-depth analysis qualitatively and quantitatively about the application of the concept of Islamic housing in the sharia housing case study shows that in the case of Medina Residence 1 it is sufficiently representative to show the application of the ideal Islamic residential concept criteria. Medina Residence 1 received an evaluation response with an average mean score of 5.381 on a scale of 6 or it can be said that $89.68 \%$ of the criteria for the concept of Islamic housing have been applied well.
\end{abstract}

Keywords: sharia housing, Islamic residential concept, Islamic housing

\section{INTRODUCTION}

Indonesian society is a religious society and upholds the values of customs and religions. The Republic of Indonesia is a country with the largest Muslim religion in the world. This causes the Indonesian people to highly uphold religious values in their lives(Kuntartianto, 2013). 
In the field of architecture, the Indonesian Muslim community is also very concerned about religious values in planning and building a building. This is demonstrated by applying the principles of Islamic architecture, which basically in terms of building a building needs to pay attention to technical, social, economic, and psychological configurations. The principles of architecture in Islam must be based on the Qur'an and Al-Hadith, so that architecture can form a good relationship between human relations and Allah SWT (hablumminallah), human relations with the natural environment (habluminal'alamin), and relationships human with fellow human beings (hablumminannas) (Edrees, 2012).

In the field of architecture, one of the most frequently developed sectors is the residential property sector, this is because the main need for people to live is increasingly rising. Therefore, there are many new residential property development projects for the community, both in the form of landed houses, midrise buildings, and highrise buildings. The need for shelter is inversely proportional to the availability of land, especially in big cities, so that the policies and strategies adopted will differ between densely populated areas and areas that have low density (Murbaintoro, 2009). One of the residential property sectors that are currently emerging is the Islamic concept of residential property that applies religious values into housing. The application of these values aims to bring religious values closer together so that the residents get special benefits in their application.

The development of real estate with a specific theme becomes a branding that can attract consumers. Many developers have raised the concept of Islamic housing as branding of developed housing products, but many housings with that concept have not met all the ideal criteria of the concept of Islamic housing both in physical and non-physical aspects, so an evaluation of the application of the concept in shari'a housing is needed. furthermore, with the application of the Islamic residential concept, sharia capital investment opportunities will arise in the property sector for investors who are interested in investing in the development of the project.

Based on the background and formulation that has been explained before, the question of this research is: How is the application of the ideal Islamic residential concept criteria for shari'a housing. The objectives of this study are evaluating the application of the ideal Islamic housing concept in the shari'a housing project.

\section{THEORY / RESEARCH METHODS}

The definition of real estate activity itself is an attempt to increase the value of a property so that it generates profits together. One of the implementations of real estate is to convert less active or vacant land into buildings so that it produces a profit. The success of real estate development is determined by how the real estate process works. In developing real estate usually goes through several stages of the process of planning and designing (Miles, 2013).

Housing can be said to have an Islamic concept if the physical or the process of housing construction is not in conflict with the provisions of Islamic sharia contained in the Qur'an and Al-Hadith. To provide a detailed picture in evaluating Islamic housing, Islamic housing principles must be formulated as a benchmark for the 
minimum criteria for evaluating housing labeled as Islamic. These principles are determined by elaborating and structuring propositions that are closely related to the built environment and the housing development process.

Apart from these arguments in the formulation of the principles of Islamic housing also added things that support these propositions, such as the background of the proposition, the inspiration of the Islamic city, and the opinions of experts. The principles of Islamic housing are grouped into three categories, namely first things that are principle (mandatory), then things that are recommended to be implemented (sunnah), and third things that are not principle (mubah) Table 1 (Amalia, 2017).

Table 1. Principle of Islamic Housing Concept

\begin{tabular}{|c|c|c|c|}
\hline No & Principle & Indicator & Phase \\
\hline 1 & $\begin{array}{l}\text { The mosque became a } \\
\text { focal point in housing } \\
\text { and made the } \\
\text { orientation of } \\
\text { activities affected by } \\
\text { religious nuances and } \\
\text { religious activities } \\
\text { (QS. Al-Baqarah:149- } \\
\text { 150) }\end{array}$ & $\begin{array}{l}\text { The mosque is surrounded by functional } \\
\text { activities of education, trade, and other } \\
\text { service facilities. } \\
\text { The mosque which is always crowded } \\
\text { with activities and is always visited for } \\
\text { prayer activities } 5 \text { times, indirectly } \\
\text { becomes a source of attraction, where the } \\
\text { rise of movement comes from the homes } \\
\text { of residents. This movement reduces the } \\
\text { possibility of isolated space, which is } \\
\text { vulnerable to crime }\end{array}$ & $\begin{array}{l}\text { Physical } \\
\text { Development } \\
\text { Planning }\end{array}$ \\
\hline 2 & $\begin{array}{l}\text { The mosque has a } \\
\text { monumental } \\
\text { impression (QS. Al- } \\
\text { Qashaash 28:77) }\end{array}$ & $\begin{array}{l}\text { The location of the mosque is easily } \\
\text { achieved and is a benchmark for } \\
\text { movement orientation into a building that } \\
\text { has its characteristics and designs }\end{array}$ & $\begin{array}{l}\text { Physical } \\
\text { Development } \\
\text { Planning }\end{array}$ \\
\hline 3 & $\begin{array}{l}\text { The mosque as a } \\
\text { generator (trigger) } \\
\text { activity and has a } \\
\text { security function in the } \\
\text { surrounding } \\
\text { environment (QS. Al- } \\
\text { Jumuah; 9) }\end{array}$ & $\begin{array}{l}\text { The mosque as a meeting point, the center } \\
\text { of worship, propaganda and teaching and } \\
\text { learning }\end{array}$ & $\begin{array}{l}\text { Physical } \\
\text { Development } \\
\text { Planning }\end{array}$ \\
\hline 4 & $\begin{array}{lr}\text { Environmental } & \text { Safety } \\
\text { Management } & \text { (QS. } \\
\text { Thalaq;6) } & \end{array}$ & $\begin{array}{l}\text { Availability of housing security facilities } \\
\text { and systems: } \\
\text { - Security post } \\
\text { - Security Unit } \\
\text { - Regulations and appeals to } \\
\text { maintain security } \\
\text { - Provision of adequate Public } \\
\text { Street Lighting }\end{array}$ & $\begin{array}{l}\text { Housing } \\
\text { Environment } \\
\text { Planning }\end{array}$ \\
\hline 5 & $\begin{array}{l}\text { Environmental Beauty } \\
\text { Management (QS. } \\
\text { Qaaf; 7) }\end{array}$ & $\begin{array}{l}\text { There is regularity in the form of the } \\
\text { absence of slums } \\
\text { There is adequate parking space } \\
\text { The maintenance of public open spaces } \\
\text { and green open spaces }\end{array}$ & $\begin{array}{l}\text { Housing } \\
\text { Environment } \\
\text { Planning }\end{array}$ \\
\hline
\end{tabular}




\begin{tabular}{|c|c|c|c|}
\hline No & Principle & Indicator & Phase \\
\hline 6 & $\begin{array}{l}\text { Health / Hygiene (QS. } \\
\text { Al- Baqarah; 222) }\end{array}$ & $\begin{array}{l}\text { Clean residential environment } \\
\text { Availability of a good waste management } \\
\text { system } \\
\text { Availability of sports facilities for } \\
\text { residents }\end{array}$ & $\begin{array}{l}\text { Housing } \\
\text { Environment } \\
\text { Planning }\end{array}$ \\
\hline 7 & $\begin{array}{l}\text { Safety and comfort of } \\
\text { road users (QS. Saba'; } \\
\text { 18) }\end{array}$ & $\begin{array}{l}\text { Good and organized road access (not } \\
\text { misleading or endangering road users) } \\
\text { The availability of a comfortable } \\
\text { pedestrian for pedestrian, elderly and } \\
\text { disability access, especially at the activity } \\
\text { centers }\end{array}$ & $\begin{array}{l}\text { Planning for } \\
\text { providing } \\
\text { additional } \\
\text { facilities }\end{array}$ \\
\hline 8 & $\begin{array}{l}\text { Following the standard } \\
\text { needs for public } \\
\text { housing facilities and } \\
\text { infrastructure (QS. Al- } \\
\text { Qamar; 49) }\end{array}$ & $\begin{array}{l}\text { Can be based on the provisions of the } \\
\text { PSU in SNI 03-1733-2004 Concerning } \\
\text { Procedures for planning the residential } \\
\text { environment in urban areas }\end{array}$ & $\begin{array}{l}\text { Planning for } \\
\text { providing } \\
\text { additional } \\
\text { facilities }\end{array}$ \\
\hline 9 & $\begin{array}{l}\text { Ease of access } \\
\text { (affordable) and } \\
\text { equitable services in } \\
\text { the provision of } \\
\text { facilities }\end{array}$ & $\begin{array}{l}\text { Social facilities such as mosques, } \\
\text { schools, clinics must be easily accessed } \\
\text { by residents }\end{array}$ & $\begin{array}{l}\text { Planning for } \\
\text { providing } \\
\text { additional } \\
\text { facilities }\end{array}$ \\
\hline 10 & $\begin{array}{l}\text { User-friendly facilities } \\
\text { (Elderly, Women, } \\
\text { Children - Children) }\end{array}$ & $\begin{array}{l}\text { In sports facilities, there needs to be a } \\
\text { separation between male and female } \\
\text { users for reasons of comfort (Can be in } \\
\text { the form of a specific usage schedule) } \\
\text { There are elderly-friendly facilities } \\
\text { (especially in shopping areas and parks) }\end{array}$ & $\begin{array}{l}\text { Planning for } \\
\text { providing } \\
\text { additional } \\
\text { facilities }\end{array}$ \\
\hline 11 & $\begin{array}{l}\text { Do not use something } \\
\text { contrary to the } \\
\text { provisions of Islamic } \\
\text { teachings (applies to } \\
\text { signage, information } \\
\text { boards, sculptures, and } \\
\text { names on the street) }\end{array}$ & $\begin{array}{l}\text { Do not install signage and information } \\
\text { boards that contain polytheistic or } \\
\text { misleading elements. } \\
\text { Do not put a statue of something lifeless } \\
\text { (figures, animals) or something that } \\
\text { contains polytheism. } \\
\text { Do not use street names taken from terms } \\
\text { that contradict or indicate polytheism. }\end{array}$ & $\begin{array}{l}\text { Planning for } \\
\text { providing } \\
\text { additional } \\
\text { facilities }\end{array}$ \\
\hline 12 & $\begin{array}{l}\text { Do Not build a house } \\
\text { that can reduce and } \\
\text { disturb the rights of } \\
\text { neighbors (QS; Al- } \\
\text { Furqan; 46) }\end{array}$ & $\begin{array}{l}\text { The maximum number of floors of a } 2 \text { - } \\
\text { story house building with a standard } \\
\text { height of a maximum of } 5 \text { meters distance } \\
\text { from tiles to the ceiling. } \\
\text { The existence of a garage or public } \\
\text { parking area to store vehicles }\end{array}$ & $\begin{array}{l}\text { House } \\
\text { planning }\end{array}$ \\
\hline 13 & $\begin{array}{l}\text { Do Not build a house } \\
\text { with the intention of } \\
\text { boasting of wealth and } \\
\text { power } \\
\text { (QS' Al-Furqan 67; } \\
\text { QS Al-Isra'; 27) }\end{array}$ & $\begin{array}{l}\text { The initial exterior design of the house is } \\
\text { not excessive }\end{array}$ & $\begin{array}{l}\text { House } \\
\text { planning }\end{array}$ \\
\hline 14 & $\begin{array}{l}\text { Do not build a house } \\
\text { with a design that }\end{array}$ & $\begin{array}{l}\text { The privacy protections of the occupants } \\
\text { of the house are pursued by the division }\end{array}$ & $\begin{array}{l}\text { House } \\
\text { planning }\end{array}$ \\
\hline
\end{tabular}




\begin{tabular}{lll}
\hline No & \multicolumn{1}{c}{ Principle } & \multicolumn{1}{c}{ Indicator } \\
\hline $\begin{array}{l}\text { allows space inside the } \\
\text { house to be seen from } \\
\text { outside the house (QS; } ;\end{array}$ & $\begin{array}{l}\text { of the territorial system which is divided } \\
\text { into private, family, semi-public, public, } \\
\text { an-Nur; 30-31) }\end{array}$ & $\begin{array}{l}\text { and special spaces based on occupancy } \\
\text { status, sex, family structure, marriage } \\
\text { ties, and maturity criteria. } \\
\text { The exterior design of the house that does } \\
\text { not provide access to the room inside the } \\
\text { house is visible from the outside }\end{array}$ \\
& Source: (Amalia, 2017)
\end{tabular}

The house in Islamic teachings must be able to accommodate a form of affection for its inhabitants. The house in Islamic teachings is also a place of worship. In this case, the house is an afdhol place to do the sunnah prayers, read the Koran, as well as a place of actual moral education for Muslim families (Hermawan, 2014).

To find out the concept of residential philosophy in Islam, we can examine one of the concepts of the concept of Islamic residential homes in Andalusia. This is due to the Andalusia region which is experiencing cultural acculturation of the Middle East with Europe which is almost the same as the condition of Islamic housing in Indonesia which is the acculturation of local, middle east, and modern culture. In building a house two things underlie the process of building a house, namely the pattern of space and outside space that forms a residential unit (Hermawan, 2014). Furthermore, some characteristics make up the house with the concept of Islamic housing (Hwaish, 2018), including:

1. Entrance access, in the context of Islamic residence in Andalusia, there are always two entrances to the house, as a separator between men's entrance access and women's entrance access

2. The separation between the living room and family room, the separation of this space is an act of providing privacy to residents.

3. The existence of the park in the house, the Andalusian community, and the Mediterranean area of open space area is a point that must be in the housing. This is intended for air circulation or natural scenery into space. This concept is also found in settlements in Dhaka Bangladesh, although in the city is very dense and dirty, the concept of the park as an element of space is still maintained (Khan, 1985).

4. Having two kinds of bedrooms separated from each other. One for parents and one for children, if girls and boys must sleep separately from the age of ten years.

5. Ventilation and natural lighting must be able to reach all rooms.

6. The house, yard, living room, and all service rooms must be clean and without dirt.

7. Can actualize the principles of Islamic behavior, especially the principles of beauty, cleanliness, and costs that are not too high, actualize the characteristics of simplicity, in residential design.

8. Using the yard for open space, both inside and in front of and behind buildings. Privacy is supported by the existence of shading gratings such as mashrabia. 
9. Room units must have privacy between one unit and another.

10. Islamic housing must be able to meet human needs based on their lifestyle, culture, environment, social, and physical nature.

11. Islamic housing must be related to family needs and sensitivity to the environment, existing resources, and building technology. Meeting needs must fulfill functions that reflect the Muslim lifestyle.

12. Applying the art and decoration of Islamic geometry, floral design, and calligraphy and not showing the beauty of the house with arrogance.

13. The height of the building must not exceed the surrounding buildings to prevent people from showing off (arrogance) and disturbing the privacy of others

14. Family Protection; a. Separation of each space according to the activities in it.; b. The right entrance to connect the house to the yard.; c. The design of the house and the materials used must be able to respond to the environmental climate.; d. Ventilation and natural lighting must be provided for all rooms.; e. Better to have a separate toilet from the bathroom.; f. Not excessive in building a house.; g. Better there is a special room for guests to maintain the privacy of residents of the house.

\section{Research Methods}

In this research that will be developed discusses the application of the concept of Islamic housing to housing, therefore the paradigm of this research is the postpositivist paradigm with the two phases combined strategy research methodology (Groat, 2013), namely in the initial stages The study was conducted a qualitative research methodology on the application of the concept of Islamic housing to the research object which will be reviewed using descriptive qualitative analysis methods (Poerwandari, 2009). After analysis, investors will be asked to ask the results of the analysis to be evaluated using interview and questionnaire techniques (Sugiyono, 2007) to determine the motives for investment selection and to what extent investor satisfaction with the results of the development of Islamic housing concept, after analysis of the two data. achieved then the relationship between the application of the concept of Islamic housing with the selection of Shari'ah investments and investor satisfaction in shari'a housing properties can be sought.

In this study, there are two types of variables, the dependent variable, and the independent variable. The independent variables in this study are the results of evaluating the application of the concept of Islamic housing in shari'a housing such as building unit design, environmental area design Table 2, The dependent variable in this study is the result of the evaluation.

Table 2. Research Variable and Sub-Variable

\begin{tabular}{|c|c|}
\hline Variable & Sub-Variables \\
\hline Building Unit & There are two entrances for men and women. \\
\hline Design & $\begin{array}{l}\text { There is a separation between the service room and the main room. } \\
\text { There is a separation between the family room and living room. } \\
\text { There is a park as the main orientation. }\end{array}$ \\
\hline
\end{tabular}




\begin{tabular}{ll}
\hline Variable & \multicolumn{1}{c}{ Sub-Variables } \\
\hline & There are Islamic-style geometry ornaments, plants, and flowers. \\
& There are shading devices and Secondary skins for the privacy of the \\
& occupants. \\
& There are ornaments at the main entrance to be the focal points of the \\
entrance design. & There is ventilation in each room \\
& There are openings of natural light that can reach the entire space \\
& Carrying the concept of climate responsiveness \\
& Building height does not exceed the surrounding environment (2 story \\
building floor, maximum tile to ceiling distance of 5 meters)
\end{tabular}

Analysis of qualitative data consists of three activities that occur simultaneously, namely data reduction, data presentation, and concluding/verification (Miles, 2014). Analysis of quantitative data obtained from the results of the questionnaire will be processed and presented in the form of a frequency distribution table to determine the response to each of the variables studied. Furthermore, a mean score statistical analysis will be performed to find out the average of the respondent's opinions on whether the quality of each of the aspects in question has met or does not meet (Sugiyono, 2007).

\section{RESULTS AND DISCUSSION}

Administratively, the location of the research object is in the Medina Residence 1 housing complex located in Klandungan Hamlet, Landungsari Village, Dau District, Malang Regency. (Figure 1) 


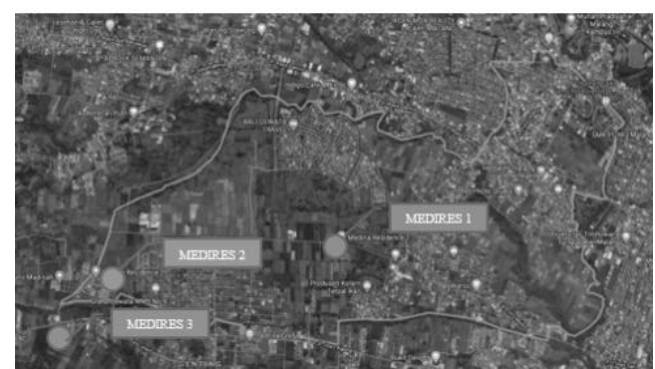

Figure 1 Map of the Research Location of Klandungan Hamlet, Landungsari Village, Dau District, Malang Regency Source:

https://www.google.com/maps/place/Dusun+Klandungan,+Landungsari,+Kec.+Dau,+Malang,+Jawa+Timur.

The object of this research is the Medina Residence 1 (Figure 2), this housing was chosen because it generally uses the shari'a concept as a whole. The application of the shari'a concept can be seen from the planning, design, funding, marketing, and estate management stages. In addition to the Medina Residence 1 housing as a comparison of the application of the concept of Islamic housing in the design of building units and areas, the comparable object of the Medina Residence 2 and 3 is used Figure 1, where both these houses are also under the same developer, PT Insan Medina Propertindo which located in a location not too far from the Medina Residence 1 housing. In general, the physical design of the housing developed by PT. Insan Medina Propertindo has characteristics and Islamic values that are almost similar but have details of the design of buildings and areas that are quite different in each housing, so it can be seen how the comparison of the three objects to be evaluated following predetermined variables, especially on the physical design aspects of residential units and regions.

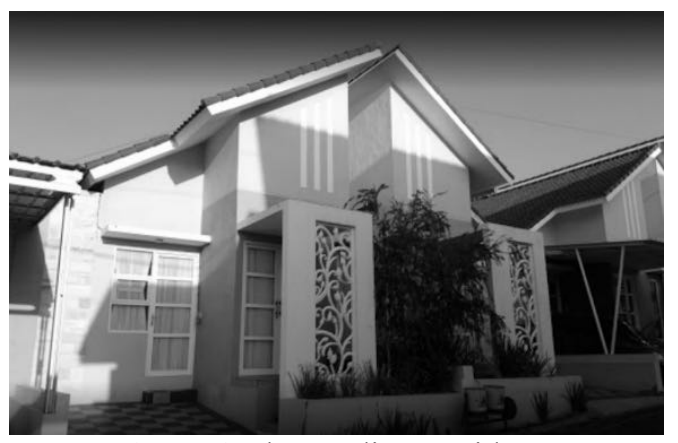

Figure 2 The Medina Residence Source: Field Survey (2020).

The subject of this research is the project investor managed by PT. Insan Medina Propertindo who funded the development of Medina Residence 1.2, and 3. The data taken is a response from the population of the investor group Medina Residence 1, 2, and 3 housing projects, which amounted to 18 people.

Considering the varied domicile location of investors, the questionnaire data collection was carried out online through the Google Form platform that was 
distributed by the developer through the investor group social networking group in February - March 2020. Before analyzing in-depth the Shari'a housing development evaluation questionnaire based on the application of the concept of Islamic occupancy and investment satisfaction are tested for validity and reliability using Cronbach Alpha statistical reliability. The minimum score of said reliable data is 0.6 . On the results of the Shari'ah housing evaluation questionnaire based on the application of the concept of Islamic housing, the reliability score is 0.962 , then the results of the questionnaire can be said to be reliable (Figure 3). The following is a test of the reliability of the shari'a housing evaluation questionnaire based on the application of the concept of Islamic housing.

\begin{tabular}{|rl|r|r|}
\multicolumn{4}{c}{ Case Processing Summary } \\
\hline & & \multicolumn{1}{c|}{$N$} & \multicolumn{1}{c|}{$\%$} \\
\hline Cases & Valid & 18 & 100.0 \\
& Excluded & 0 & .0 \\
& Total & 18 & 100.0 \\
\hline
\end{tabular}

a. Listwise deletion based on all variables in the procedure.

Reliability Statistics
\begin{tabular}{|c|r|}
\hline $\begin{array}{c}\text { Cronbach's } \\
\text { Alpha }\end{array}$ & N of Items \\
\hline .962 & 52 \\
\hline
\end{tabular}

Figure 3 Image of the results of the reliability test of the Shari'ah housing evaluation questionnaire based on the application of the Islamic residential concept Source: Statistic analysis use SPSS

In addition to investor responses taken as an analytical material for the application of Islamic residential concepts quantitatively, data from interviewees who were the first investors in the Medina Residence housing who also have an educational background in Architecture can provide in-depth qualitative answers and reasons from the response given. The investor representatives interviewed in this study were the first Investors in the Medina Residence housing development project so that they knew the ins and outs of housing development at Medina Residence from the planning stage to estate management.

\section{Analysis of Building Unit Design}

1. The existence of two entrances (for men and women).
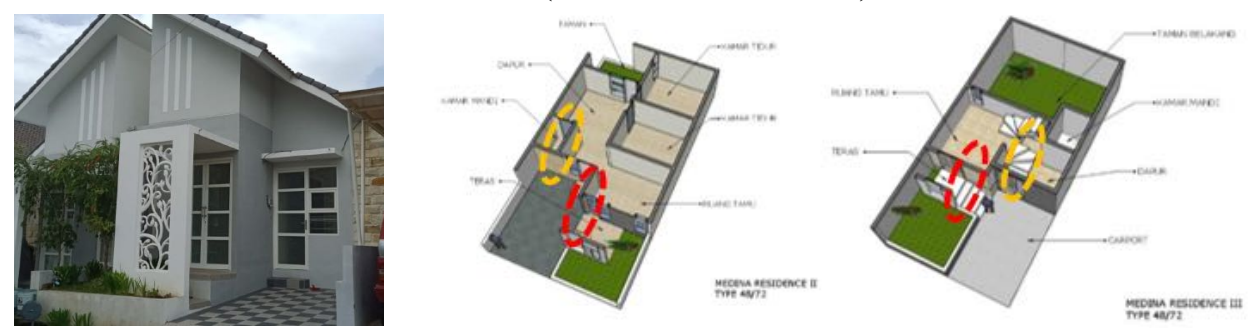

Figure 4 Access the entrance of Medina Residence 1 (left) Medina Residence 2 (middle)

Medina residence 3 (right)

Source: Field Survey 2020 
In the documentation of the residential area (Figure 4) can be indicated in the Medina Residence 1 housing, has provided two access entrances, with main door access to the living room and second door access to the kitchen and family room, the position of the side door can be directly accessed from the carport but the design uses glass so it does not maintain the privacy of residents. As a comparison, Medina Residence 2 and 3 have also provided two access entrances, where the main door directly leads to the living room, as well as a side door that can be accessed from the carport and towards the kitchen and family room.

2. The existence of a separation between the service room and the main room.
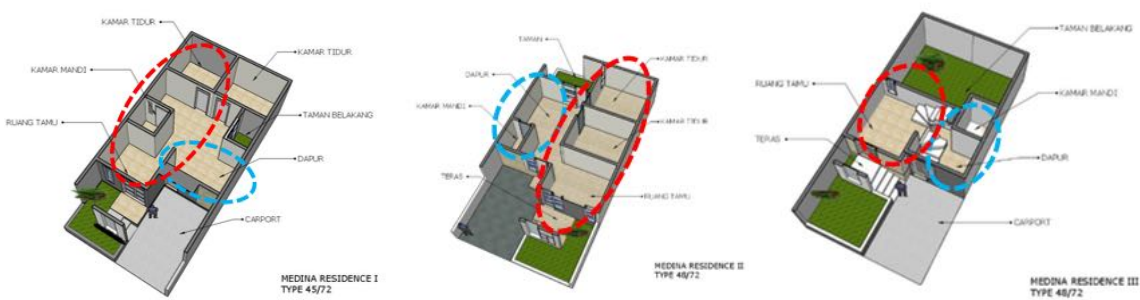

Figure 5 Medina residence 1(left),2 (middle), and 3(right) main room and service room Source: Field Survey 2020

In Figure 5, that is the residence of Medina Residence 1 service area and the main room has been separated by a dividing wall, but the hierarchy of the space is not visible so that there is still little visible service room condition from the family room, this is due to limited land and building area. As a comparison, Medina Residence 2 housing uses the same concept as Medina Residence 1. While Medina residence 3 has implemented the separation of the service room and main room with the split level concept. Placement of the service room can be seen at that is located at the lowest floor level, parallel to the carport. Meanwhile, to get to the living room or main door, the height of the building is raised slightly as high as 1 meter so that the hierarchy of space is more pronounced.

3. The existence of a separation between the family room and living room.
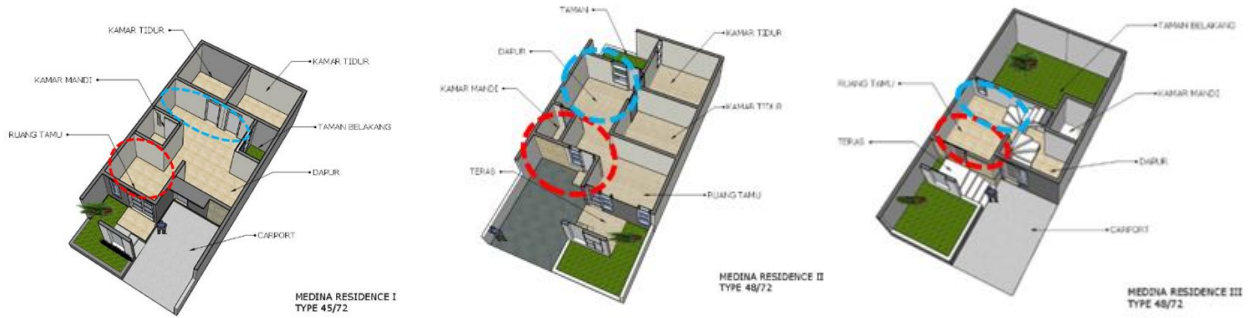

Figure 6 Layout family room of Medina Residence 1, 2, and 3

Source: Field Survey 2020

In Figure 6, the Medina Residence 1 housing area and family room area are separated, with placement according to the picture so that the family room is not seen directly from the living room. While as comparison Medina Residence 2 family rooms 
are still integrated with the kitchen but separate from the living room. At Medina Residence 3 there is no massive separation between the living room and family room.

4. The existence of the park in the building lots.
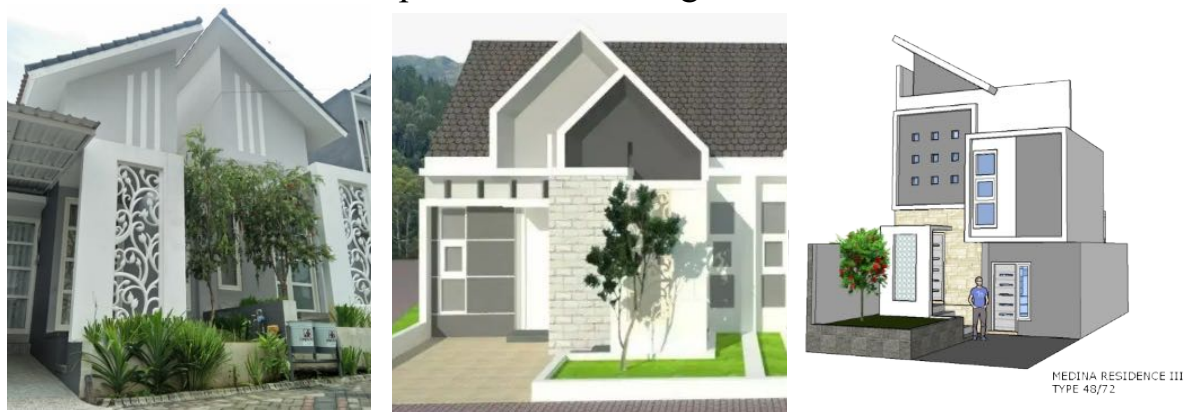

Figure 7 The garden in building units of Medina Residence 1 (left), 2 (middle), and 3 (right) Source: Field Survey 2020

In the documentation of the housing area (Figure 7) can be indicated in the housing Medina 1, has provided a garden in the front and center of the house for greening, aesthetics, lighting, and airing this design adopts the concept of an inner courtyard in Muslim homes in the Middle East. As a comparison, Medina Residence 2 and 3 have also applied the concept of green space in each building unit. Then also in the rear area of the residential unit provides a garden to facilitate the refreshing room of housewives without the hassle of using the hijab. The park can also be used as a sunroom and a source of natural lighting and air.

5. The existence of shading devices and secondary skin for the privacy of residents.

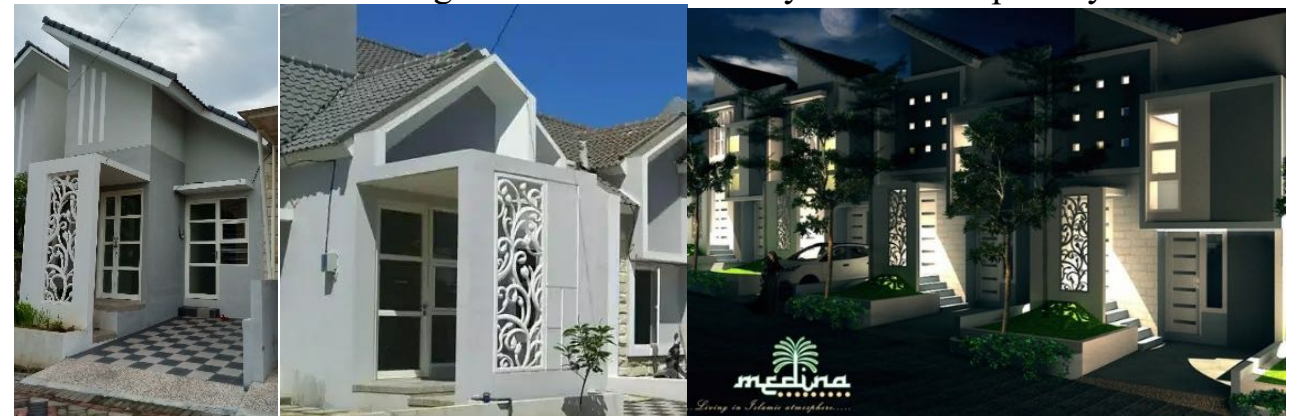

Figure 8 Secondary skin and shading device on the front of the building unit Medina Residence 1 (left), 2 (middle), and 3 (right) Source: Field Survey 2020

In Figure 8, the field documentation at Medina Residence 1, has implemented shading devices and secondary skins for the privacy of residents. The placement in the front of the living room surrounding the terrace of the house can limit visual access from outside to inside the house. The style used for secondary skin nuances of Islam with plant motifs. As a comparison, Medina residence 2 and 3 also apply shading devices and secondary skins on each building unit, but the proportions of solid and void vary. 
6. The existence of Islamic geometric style ornaments, plants, and flowers

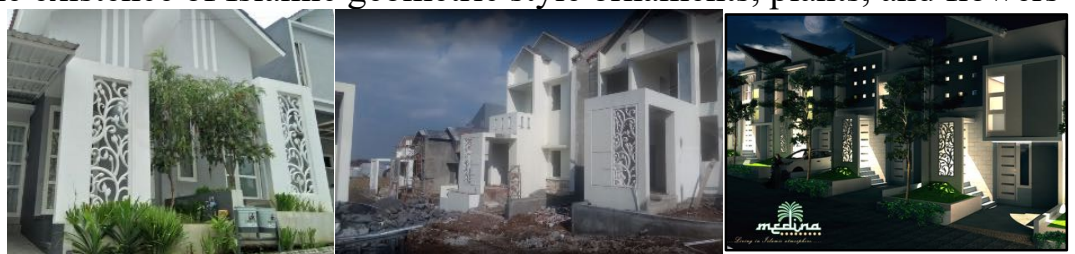

Figure 9 Plant motifs on the entrance unit of the of Medina Residence 1 (left), 2 (middle), and 3 (right)

Source: Field Survey 2020

In Figure 9, the field documentation at Medina Residence 1, has implemented an Islamic nuance style with plant motifs applied to the patio enclosures, made of concrete. As a comparison, Medina residence 2 and 3 also apply Islamic nuances to the entrance unit of the building.

7. The presence of ventilation in each room.
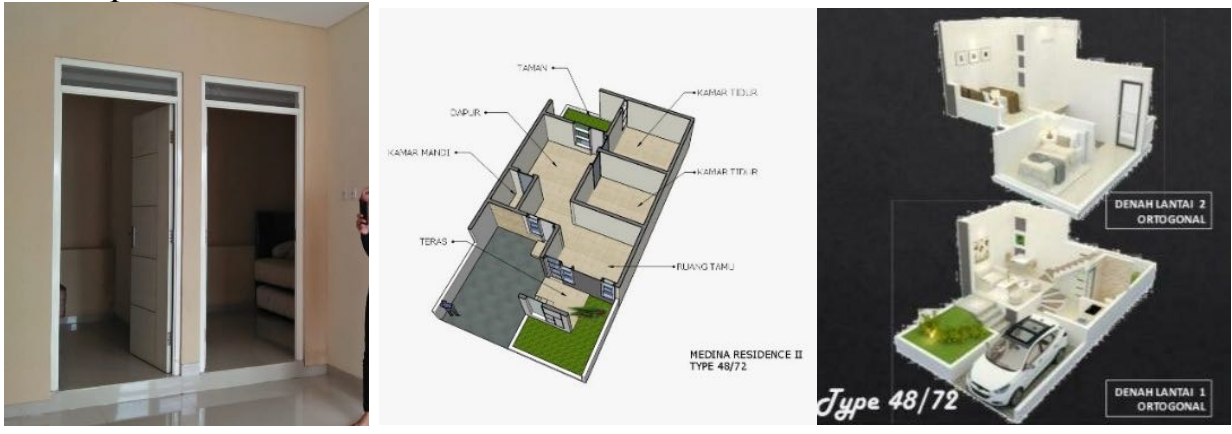

Figure 10 Ventilation in space ofMedina Residence 1 (left), 2 (middle), and 3 (right) Source: Field Survey 2020

In Figure 10 of the Medina Residence 1 building, there is ventilation in each room above the door. This helps the air circulation to move easily in and out of the room in the house. To access ventilation to the outside of the building using windows on the front and window openings in the middle garden of the building unit. As a comparison, Medina residence 2 and 3 there are also vents in each room of each building unit in the form of windows and ventilation above the door.

8. The existence of natural light openings that can reach the entire space
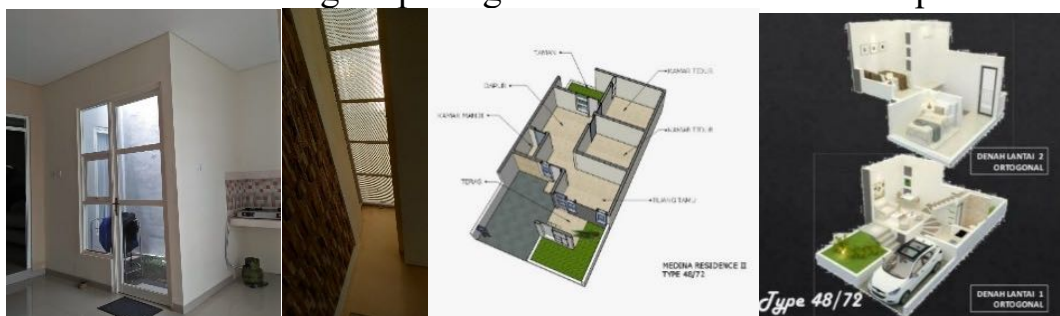

Figure 11 Access natural lighting in Medina Residence 1(left), 2 (middle), and 3 (right) Source: Field Survey 2020 
In Figure 11 of the Medina Residence 1 building, there are openings in each room in the form of windows and glass blocks. This helps natural lighting in the building. In the living room area, there are window openings in the middle of the building unit and there are voids in the middle of the building. As a comparison, in Medina residence 2 and 3 there are also openings in each room of each building unit. This also shows that the other two houses also use natural lighting as the main lighting source during the day.

9. Carrying the concept of climate responsiveness.
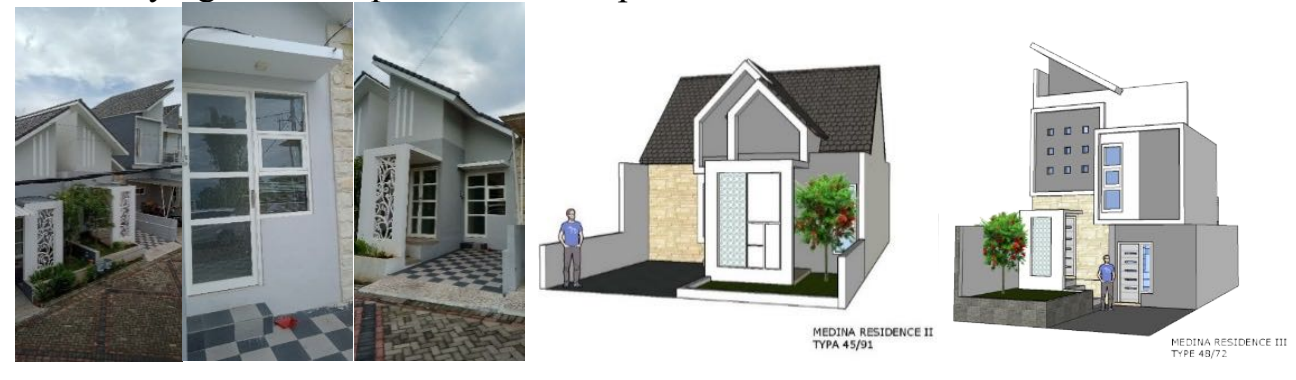

Figure 12 Climate responsiveness of building units in Medina Residence 1(left), 2 (middle), and 3 (right)

Source: Field Survey 2020

In Figure 12 Medina Residence 1 building units are seen using the concept of a wet tropical sloping roof where rainfall is quite high. In the design of buildings using cast gutters for the path of the fall of water, this is intended to prevent leakage in the house. Furthermore, each opening is equipped with shading devices in response to the wet tropical climate in Indonesia. As a comparison, Medina residence 2 and 3 also applies the concept of climate response to the building units that are developed. This is indicated by the presence of shading devices and tropical roof scopes.

10. Building height does not exceed the surrounding environment ( 2 story building floor, maximum tile to ceiling distance of 5 meters)
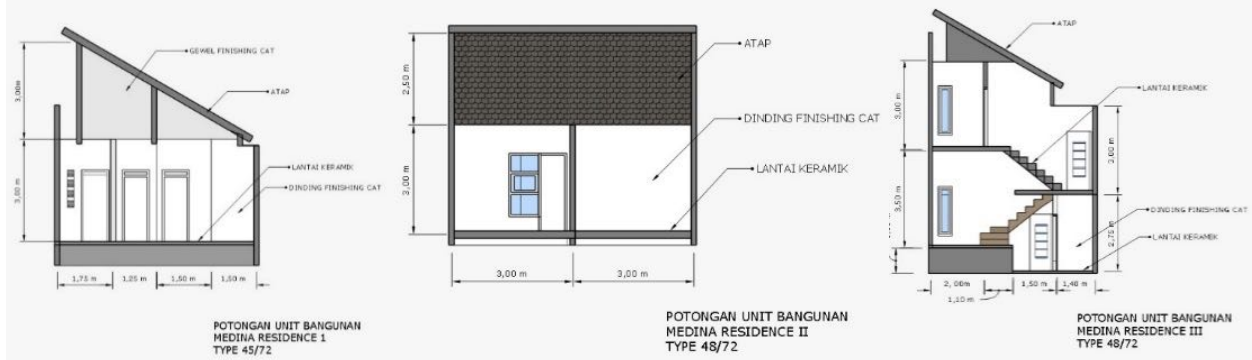

Figure 13 Ceiling and building height of Medina Residence 1(left), 2 (middle), and 3 (right) Source: Field Survey 2020

In Figure 13 the Medina Residence 1 building unit has a ceiling height as high as $\pm 3 \mathrm{~m}$ so that the height of the building does not exceed the surrounding environment, especially the mosque located in the Medina Residence 1 residential 
area. As a comparison, Medina residence 2 also has a ceiling height between 3 - 3.5 $\mathrm{m}$, so the height of the building also does not exceed the surrounding buildings, especially mosques in housing.

\section{Analysis of Environmental Area Design}

11. The existence of representative support facilities for worship.
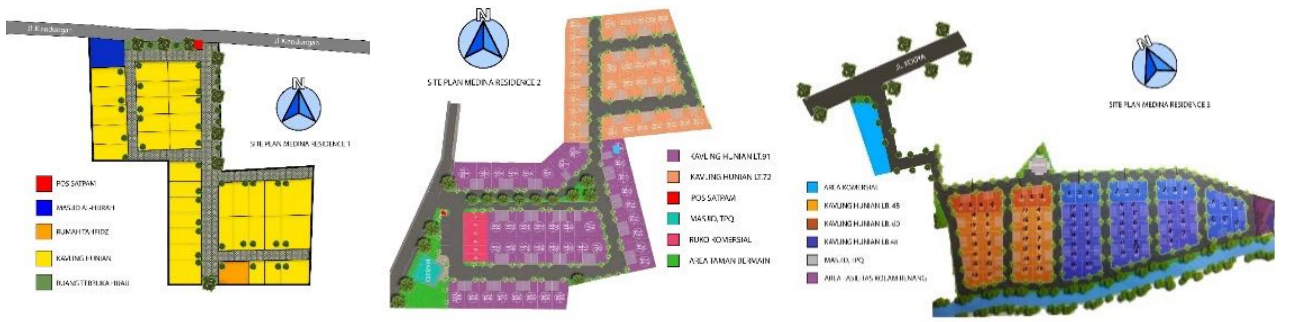

Figure 14 Worship facilities in the Site Plan of Medina Residence 1(left), 2 (middle), and 3 (right)

Source: Field Survey 2020

In the housing area site plan Figure 14 can be indicated in the Medina Residence 1 housing there is a supporting facility for worship in the form of a mosque, with the name Al-Hijrah Mosque located at the front of the housing area. As a comparison for Medina Residence 2 housing, there are also religious support facilities located at the front of the area so that it is sufficient to represent the characteristics of Islamic housing. Whereas in the Medina Residence 3 housing the mosque is in the front area of the housing block but is not seen directly from the main access road.

12. The existence of representative supporting security infrastructure (security post, PJU).
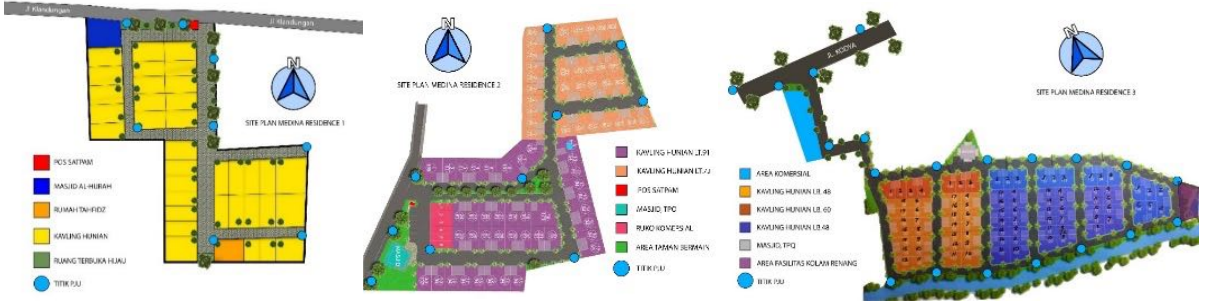

Figure 15 Location of Laying of Security Posts and Post Lamp Points of Medina Residence 1(left), 2 (middle), and 3 (right)

Source: Field Survey 2020

In the site plan and housing area documentation Figure 15 can be indicated in the Medina Residence 1 housing, there are security supporting infrastructure facilities in the form of one gate system, and PJU on the part of the road within the residential area and towards housing. Laying a security post is located at the main entrance of the housing in front of the residential area. As a comparison, there are also Medina Residence 2 and 3 housing facilities supporting security facilities in the form of one gate system and PJU facilities which can be seen from the picture of the PJU point plan and the Site Plan. 
13. The existence of representative sanitation infrastructure facilities
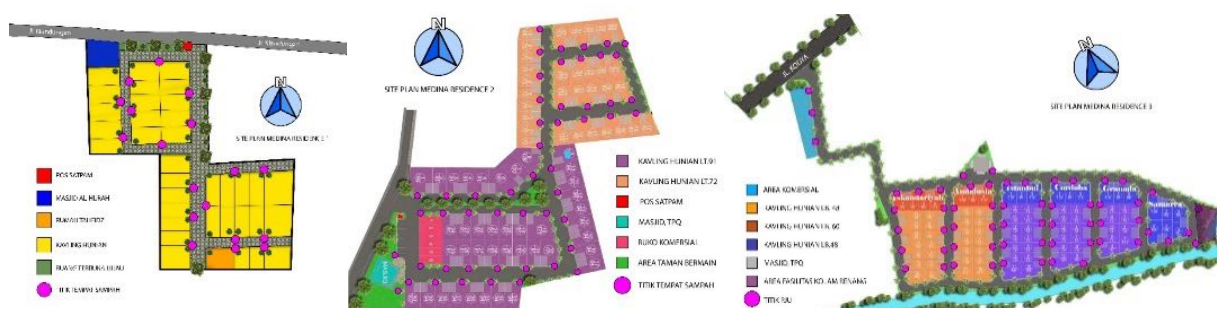

Figure 16 Location of Laying Points of Trash of Medina Residence 1(left), 2 (middle), and 3 (right)

Source: Field Survey 2020

On the site plan and housing area documentation (Figure 16) can be indicated in the Medina Residence 1 housing, there are sanitation infrastructure facilities in the form of organic and inorganic rubbish bins in the front area of the two lots of residential units in the housing area. The design of the trash can using paint cans is also a way to utilize construction waste from the Medina Residence housing. However, Medina Residence 1 does not have a TPS and does not allow the existence of TPS because the land is quite limited. The different types of waste make the management of solid waste in Medina Residence 1 housing meet Islamic residential criteria. As a comparison, there are also Medina Residence 2 and 3 housing facilities that support hygiene infrastructure which can be seen in the following draw point plan for the trash.

14. The existence of regional utility infrastructure facilities (electricity, water, telephone/internet).
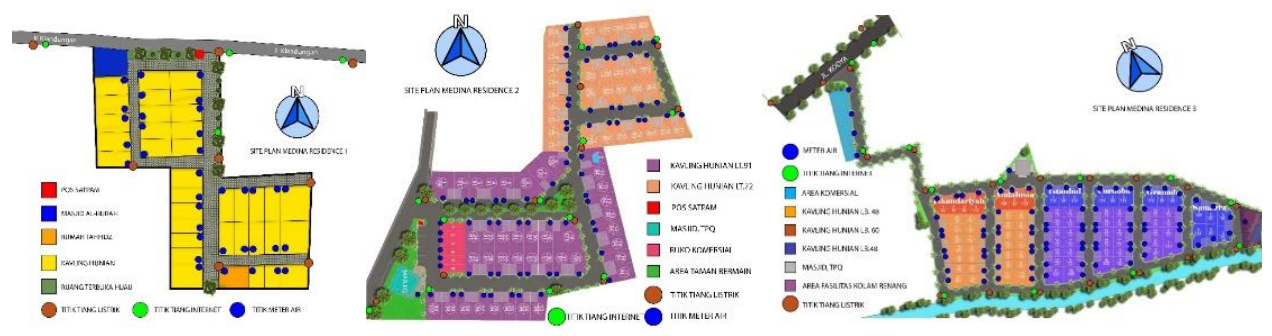

Figure 17 Regional Utility Plan of Medina Residence 1(left), 2 (middle), and 3 (right) Source: Field Survey 2020

In the site plan and housing area documentation (Figure 17) can be indicated in the Medina Residence 1 housing, there is a fairly complete area of utility infrastructure in the form of the electricity network, regional independent water network, and fiber optic internet network, but laying down the network is still using poles or Medium Voltage Electricity Networks (SUTM). As for clean water, artesian wells are managed by groups of residents whose profits are used mainly for the prosperity of the mosque. As a comparison in Medina Residence 2 and 3 housing, there are also regional utility infrastructure facilities that can be seen in the drawings of the electricity network plan, clean water distribution, and the internet as follows. 
15. Presence of shared space (community hall, sports field, playground)
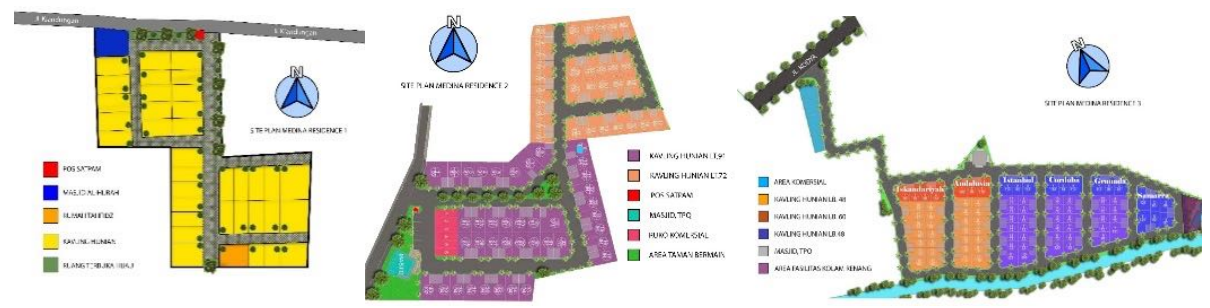

Figure 18 Public Space Plan of Medina Residence 1(left), 2 (middle), and 3 (right) Source: Field Survey 2020

In the site plan and housing area documentation (Figure 18) can be indicated in the Medina Residence 1 housing area there is an open park area that can be utilized in the future as a playground or a relaxing park. At present, the condition is only planted with ornamental plants to add to the aesthetics of the region so that it does not include active shared space. The location is next to the house of Tahfidz. As a comparison in Figure 4.30 and Figure 4.31, Medina Residence 2 and 3 housing there is also a larger shared room facility that can be used for recreation areas and shared spaces of residential residents. At Medina Residence 2 there is a planned playground area in the area around the mosque, while Medina Residence 3 is planned to be a swimming pool area that can be used as a recreational facility for residents. According to the developer at Medina Residence 3, the swimming pool area is also held to support one of the Sunnah sports, which is swimming, and on certain days will be programmed for special use by women to maintain privacy and comfort for users. The location of facilities can be seen in the following Medina Residence 2 and 3 site plans.

16. Existence of Educational facilities (Formal / Informal).
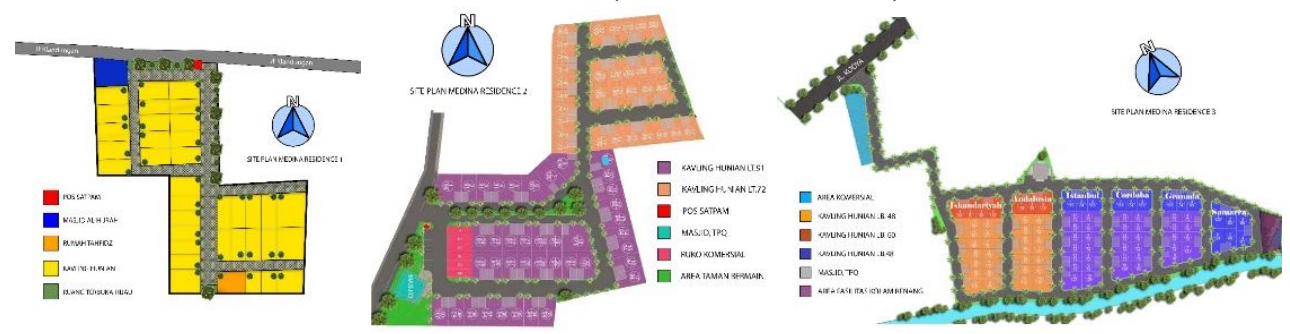

Figure 19 Tahfidz House Location and Integrated TPQ plan of Medina Residence 1(left), 2 (middle), and 3 (right)

Source: Field Survey 2020

In the site plan and housing area documentation (Figure 19) can be indicated in the Medina Residence 1 housing, there is a Tahfidz Quran house located in lot 33 as shown in the Medina Residence 1 site plan above. Furthermore, the location of Medina Residence 1 is only $300 \mathrm{~m}$ from the Tazkia IIBS Putri International boarding school and $1 \mathrm{~km}$ from the Tazkia IIBS Putra International boarding school which is still located on the main access. In addition to higher education that breathes Islam, the location of Medina Residence 1 is only $2 \mathrm{Km}$ from the University of Muhammadiyah Malang Campus. As a comparison Medina Residence 2 and 3 
housing there is also an integrated TPQ plan with the Mosque. The existence of TPQ in shari'a housing is one of the characteristics of Islamic housing in which Al-Quran education is one of the main points in realizing the Islamic concept of housing.

17. The existence of health facilities (posyandu, clinics, etc.).

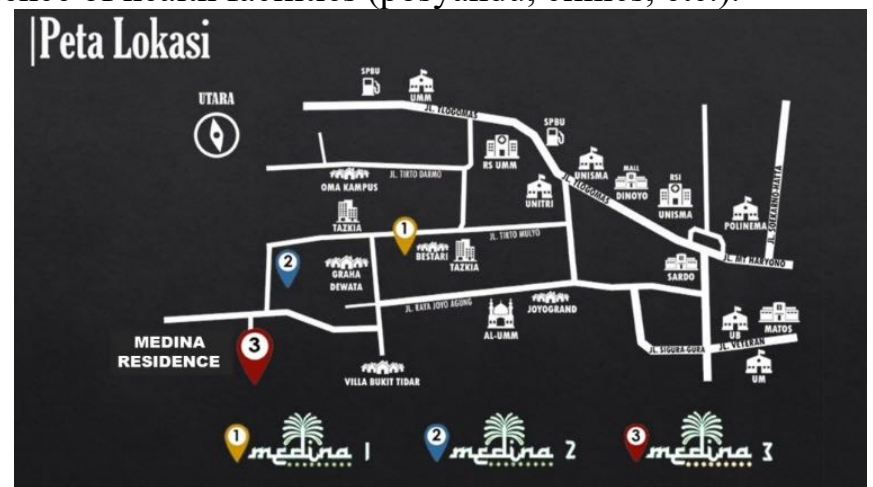

Figure 20 Location of public health facilities of Medina Residence 1(left), 2 (middle), and 3 (right)

Source: Field Survey 2020

In the Site plan and map (Figure 20) can be indicated that housing Medina Residence 1 does not yet have a health facility within the housing area, but the location of Medina Residence 1 is quite close to a health facility in the form of a hospital which is $2 \mathrm{~km}$ from the housing location, so it needs to develop clinical facilities / multipurpose building for posyandu. As a comparison, Medina Residence 2 and 3 housing following the plan also does not yet have the health support infrastructure in the form of a special clinic or shared space for posyandu. However, according to the plan to develop the facility, it can be added to the integrated land located in the front of the housing area.

18. The existence of commercial or shopping facilities (stalls/shops).

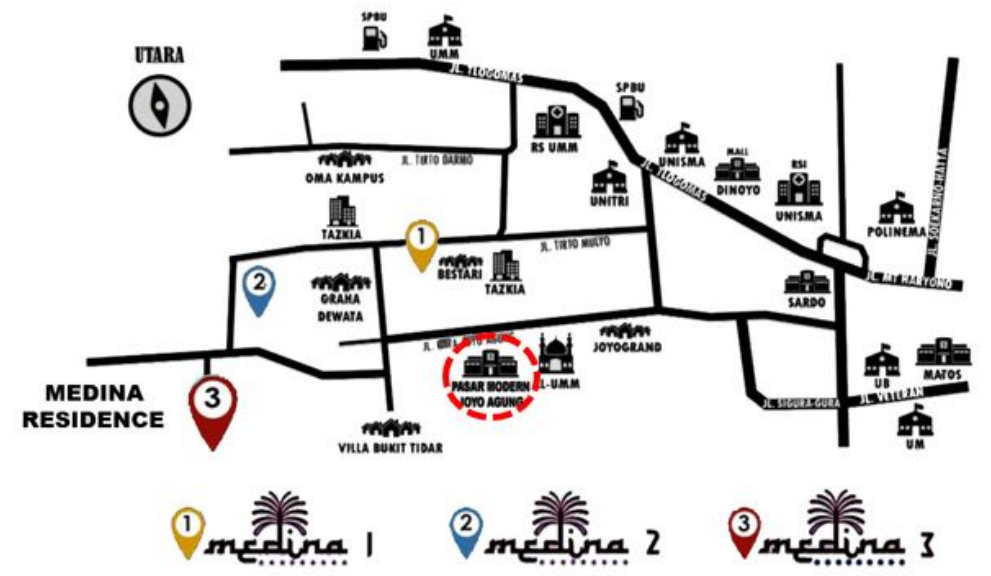

Figure 21 Location of commercial facilities of Medina Residence 1(left), 2 (middle), and 3 (right)

Source: Field Survey 2020 
On the Site plan and map, (Figure 21) can be indicated that the Medina Residence 1 housing complex does not yet have shopping facilities within the residential area, but the location of Medina Residence 1 is quite close to the shopping facility in the form of Joyo Agung Modern Market which is $1 \mathrm{~km}$ from the housing location. However, for daily needs, stalls, or shopping places that provide daily necessities are still needed. As a comparison, Medina Residence 2 and 3 housing according to the plan already has a commercial facility in the form of a business center located in the entrance area of the residential area.

19. The location of regional infrastructure facilities is easily accessible and userfriendly for the elderly, women, and children.
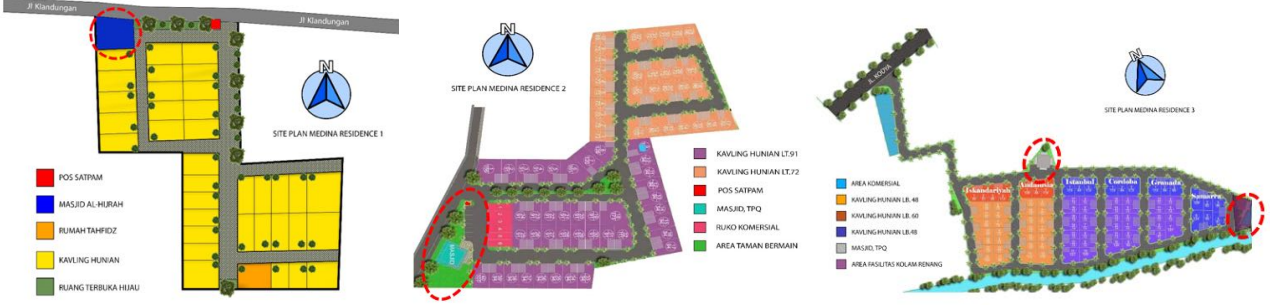

Figure 22 Accessibility location of infrastructure facilities of Medina Residence 1(left), 2 (middle), and 3 (right) Source: Field Survey 2020

In the housing area documentation (Figure 22) can be indicated in the Medina Residence 1 housing area infrastructure facilities are quite easily accessible, but there are not yet some security elements for the elderly to design the mosque in the Medina Residence 1 housing, so it needs to be developed for a more elderly-friendly design by using a ramp and railing making it easy for elderly people to access. As a comparison, Medina Residence 2 and 3 housing according to the plan will also have a fairly accessible infrastructure, which is located in the public area of each housing, but it is not yet known what the existing conditions of the infrastructure are. because it is still under construction.

20. There are no 3D ornaments/works in the form of animals/humans.
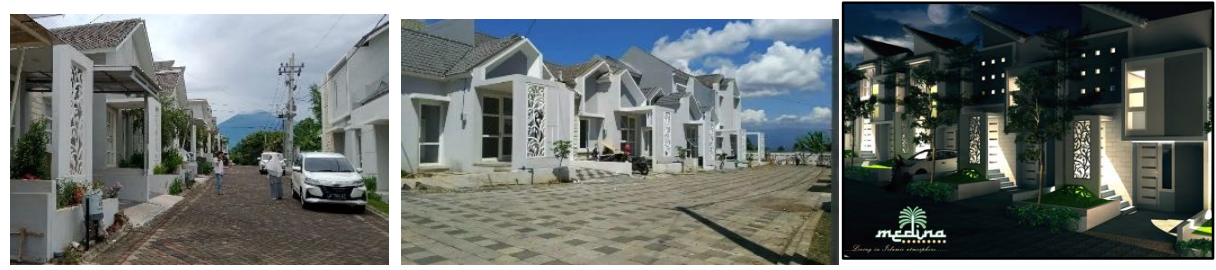

Figure 23 3D ornaments and works of Medina Residence 1(left), 2 (middle), and 3 (right) Source: Field Survey 2020

The following Figure 23 can be indicated in the Medina Residence 1 housing, there are no ornament or 3-dimensional works in the form of animals or humans, all the ornaments in the housing area and residential units are geometric in shape and plant form so that they meet Islamic residential criteria where Islamic sharia is 
prohibited from making an ornament and 3-dimensional works in the form of humans and animals. As a comparison, namely the Medina Residence 2 and 3 housing according to the plan do not use ornaments or 3-dimensional works in the form of humans or animals. One of the characteristics of the Medina Residence housing is the use of plant vines as an ornament and aesthetic visual barriers.

21. The existence of supporting vegetation area.
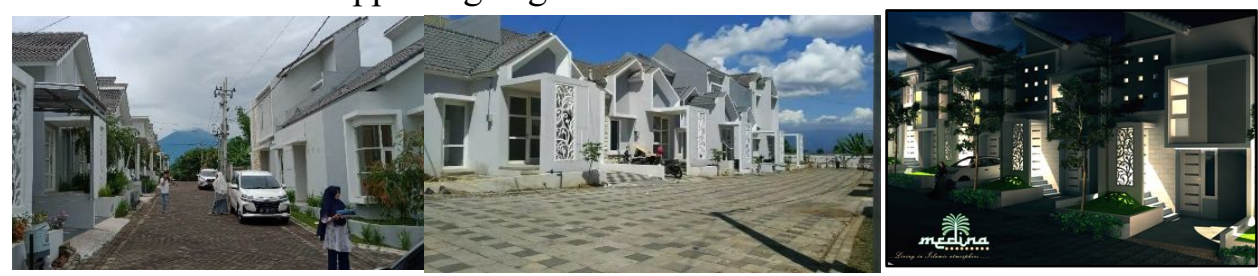

Figure 24 Supporting vegetation of Medina Residence 1(left), 2 (middle), and 3 (right) Source: Field Survey 2020

The following Figure 24 can be indicated in the Medina Residence 1 housing there is vegetation supporting the area with ornamental plant types in the form of red shoots, palms, lee Kwan yew, and bottle brushes. As a comparison, namely the Medina Residence 2 housing there is vegetation supporting the area similar to that of Medina Residence 1. In medina Residence 3 according to the planning drawings will also be equipped with vegetation supporting the area following the Medina Residence 3 site plan.

Table 3. Descriptive Statistics Analysis of Investor Evaluation in Medina Residence 1 Project

\begin{tabular}{|c|c|c|c|c|c|c|}
\hline No & $\begin{array}{l}\text { Va } \\
\text { ria } \\
\text { ble }\end{array}$ & Sub - Variable & Min & Max & $\begin{array}{l}\text { Mean } \\
\text { score }\end{array}$ & $\begin{array}{c}\text { Std. } \\
\text { Deviat } \\
\text { ion }\end{array}$ \\
\hline 1 & & There are two entrances (for men and women). & 4 & 6 & 5.278 & 0.752 \\
\hline 2 & & $\begin{array}{l}\text { There is a separation between the service room } \\
\text { and the main room. }\end{array}$ & 5 & 6 & 5.611 & 0.502 \\
\hline 3 & & $\begin{array}{l}\text { The existence of a separation between the } \\
\text { family room and living room. }\end{array}$ & 5 & 6 & 5.556 & 0.511 \\
\hline 4 & & The existence of the park in the building lots & 5 & 6 & 5.667 & 0.485 \\
\hline 5 & 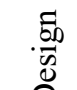 & $\begin{array}{l}\text { The existence of shading devices and } \\
\text { secondary skin for the privacy of residents. }\end{array}$ & 5 & 6 & 5.667 & 0.485 \\
\hline 6 & 莹 & $\begin{array}{l}\text { The existence of Islamic geometric style } \\
\text { ornaments, plants, and flowers }\end{array}$ & 4 & 6 & 5.333 & 0.594 \\
\hline 7 & $a_{0}$ & The presence of ventilation in each room & 4 & 6 & 5.444 & 0.616 \\
\hline 8 & $\stackrel{\Xi}{\Xi}$ & $\begin{array}{l}\text { The existence of natural light openings that can } \\
\text { reach the entire space }\end{array}$ & 4 & 6 & 5.278 & 0.752 \\
\hline 9 & $\bar{\oplus}$ & Carrying the concept of climate responsiveness & 5 & 6 & 5.556 & 0.511 \\
\hline 10 & & $\begin{array}{l}\text { Building height does not exceed the } \\
\text { surrounding environment ( } 2 \text { story building } \\
\text { floor, maximum tile to ceiling distance of } 5 \\
\text { meters) }\end{array}$ & 4 & 6 & 5.389 & 0.698 \\
\hline
\end{tabular}




\begin{tabular}{|c|c|c|c|c|c|c|}
\hline No & $\begin{array}{l}\text { Va } \\
\text { ria } \\
\text { ble }\end{array}$ & Sub - Variable & Min & Max & $\begin{array}{l}\text { Mean } \\
\text { score }\end{array}$ & $\begin{array}{l}\text { Std. } \\
\text { Deviat } \\
\text { ion }\end{array}$ \\
\hline 11 & & $\begin{array}{l}\text { The existence of representative support } \\
\text { facilities for worship. }\end{array}$ & 5 & 6 & 5.611 & 0.502 \\
\hline 12 & & $\begin{array}{l}\text { The existence of representative supporting } \\
\text { security infrastructure (security post, PJU) }\end{array}$ & 5 & 6 & 5.778 & 0.428 \\
\hline 13 & & $\begin{array}{l}\text { The existence of representative sanitation } \\
\text { infrastructure facilities }\end{array}$ & 4 & 6 & 5.556 & 0.616 \\
\hline 14 & 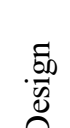 & $\begin{array}{l}\text { The existence of regional utility infrastructure } \\
\text { facilities (electricity, water, telephone / } \\
\text { internet) }\end{array}$ & 3 & 6 & 5.278 & 0.958 \\
\hline 15 & $\stackrel{0}{\overparen{J}}$ & $\begin{array}{l}\text { Presence of shared space (community hall, } \\
\text { sports field, playground) }\end{array}$ & 3 & 6 & 5.278 & 0.752 \\
\hline 16 & 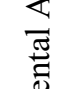 & $\begin{array}{l}\text { Existence of Educational facilities (Formal / } \\
\text { Informal) }\end{array}$ & 4 & 6 & 5.389 & 0.698 \\
\hline 17 & 咅 & $\begin{array}{l}\text { The existence of health facilities (posyandu, } \\
\text { clinics, etc.) }\end{array}$ & 2 & 6 & 4.444 & 1.097 \\
\hline 18 & 空 & $\begin{array}{l}\text { The existence of commercial or shopping } \\
\text { facilities (stalls / shops) }\end{array}$ & 2 & 6 & 4.333 & 0.970 \\
\hline 19 & & $\begin{array}{l}\text { The location of regional infrastructure facilities } \\
\text { is easily accessible and user-friendly for the } \\
\text { elderly, women, and children. }\end{array}$ & 5 & 6 & 5.333 & 0.485 \\
\hline 20 & & $\begin{array}{l}\text { There are no 3D ornaments/works in the form } \\
\text { of animals/humans. }\end{array}$ & 4 & 6 & 5.611 & 0.502 \\
\hline 21 & & The existence of supporting vegetation area. & 5 & 6 & 5.611 & 0.502 \\
\hline
\end{tabular}

Based on the analysis of the mean score in Table 3, Medina Residence 1 housing has fulfilled 21 criteria of the ideal Islamic housing concept. However, according to the results of the analysis of the interview results, it is known that several factors still need to be improved so that the quality of the Medina Residence 1 housing becomes more ideal as an Islamic Residential. Some respondents gave a less agreeing response to the sub-variable the existence of health facilities (posyandu, clinic, etc.) with a mean score of 4.444 and the existence of commercial or shopping facilities (stalls/shops) with a mean score of 4.333. To improve the quality in the future, every housing with the concept of Islamic housing must have commercial and health area facilities or a special strategy can be carried out with a routine program of sharia market management and sharia-based treatment as suggested by the investor representative in the interview. Thus, this will make Medina Residence 1 housing able to fulfill the ideal concept of Islamic housing.

Table 4. Research Findings of the Ideal Islamic Housing Concept

\begin{tabular}{|c|c|c|}
\hline No & $\begin{array}{l}\text { Vari } \\
\text { able }\end{array}$ & Research Findings \\
\hline 1 & 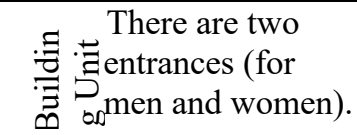 & $\begin{array}{l}\text { - There is a distinguishing design between doors for } \\
\text { men and women. } \\
\text { - There is more privacy for women's access doors }\end{array}$ \\
\hline
\end{tabular}




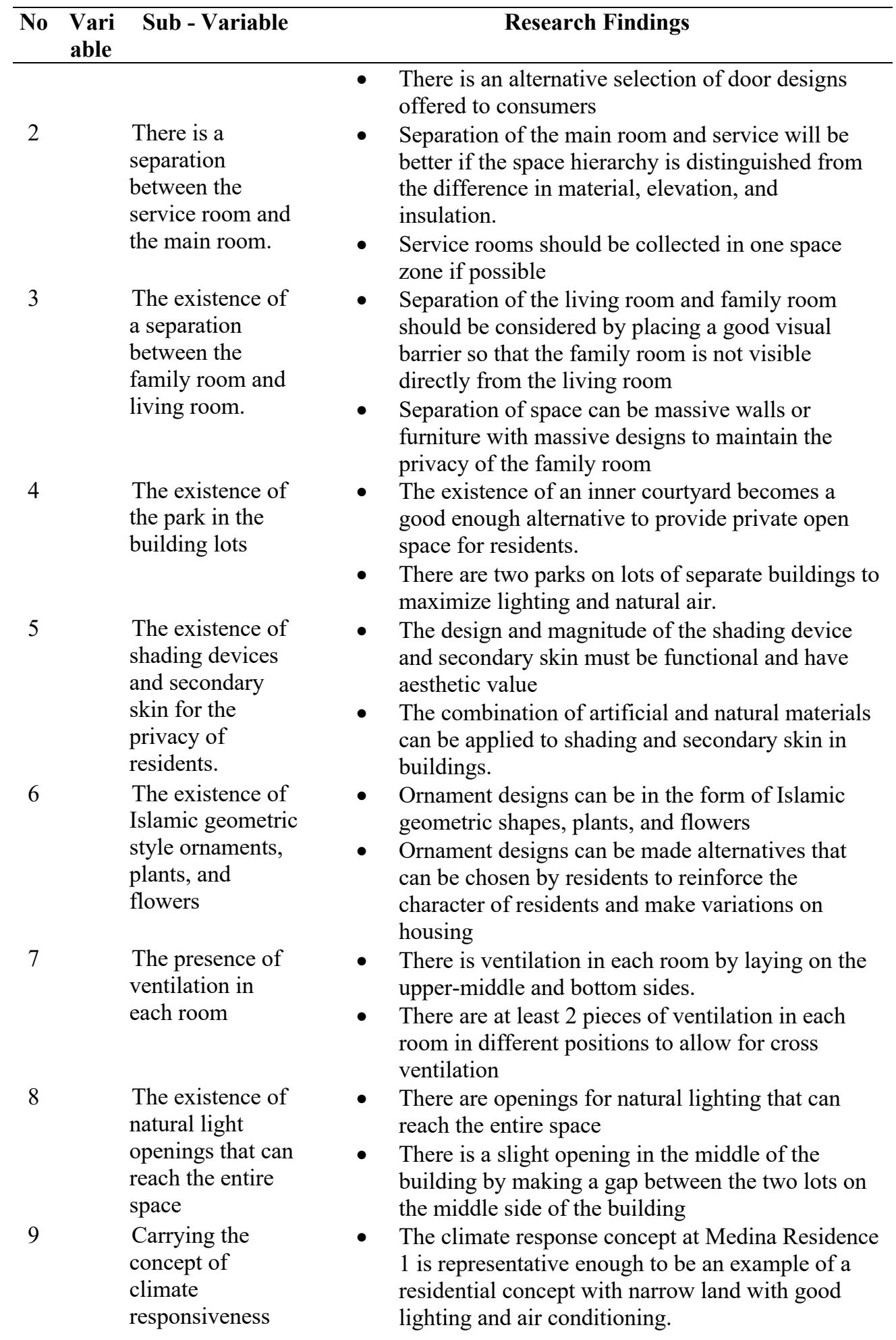




\begin{tabular}{|c|c|c|c|}
\hline No & $\begin{array}{l}\text { Vari } \\
\text { able }\end{array}$ & Sub - Variable & Research Findings \\
\hline 10 & & $\begin{array}{l}\text { Building height } \\
\text { does not exceed } \\
\text { the surrounding } \\
\text { environment ( } 2 \\
\text { story building } \\
\text { floor, maximum } \\
\text { tile to ceiling } \\
\text { distance of } 5 \\
\text { meters) }\end{array}$ & $\begin{array}{l}\text { The climate response concept applied should pay } \\
\text { attention to aspects of building orientation, } \\
\text { placement of openings, placement of shading } \\
\text { devices, placement of cross ventilation, and } \\
\text { placement of secondary skin. } \\
\text { The maximum height from the floor to the ceiling } \\
\text { is } 5 \text { meters for 1-story buildings and } 4 \text { meters for } \\
\text { buildings of } 2 \text { floors or more } \\
\text { The height of the residential building does not } \\
\text { exceed the height of the mosque as the highest } \\
\text { hierarchy in the residential area. }\end{array}$ \\
\hline 11 & & $\begin{array}{l}\text { The existence of } \\
\text { representative } \\
\text { support facilities } \\
\text { for worship. }\end{array}$ & $\begin{array}{l}\text { Worship facilities should be seen from the main } \\
\text { access to characterize Islamic residences } \\
\text { The ideal distance to the nearest worship facility to } \\
\text { the farthest residential unit between } 100-165 \\
\text { meters } \\
\text { The proportion of land and buildings must be } \\
\text { balanced following the number of residential units } \\
\text { with ideal conditions for the area of worship } \\
\text { facilities } 5-10 \%\end{array}$ \\
\hline 12 & 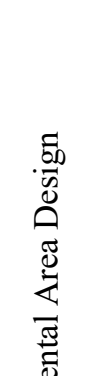 & $\begin{array}{l}\text { The existence of } \\
\text { representative } \\
\text { supporting } \\
\text { security } \\
\text { infrastructure } \\
\text { (security post, } \\
\text { PJU) }\end{array}$ & $\begin{array}{l}\text { - There are a security post and security system at the } \\
\text { entrance to the housing } \\
\text { - It would be better if you use the concept of one } \\
\text { gate system to facilitate security surveillance } \\
\text { - There are PJU points at each intersection and PJU } \\
\text { on each front of the lots } \\
\text { - For large enough residential areas, it should be } \\
\text { accompanied by CCTV facilities to facilitate } \\
\text { security. }\end{array}$ \\
\hline 13 & 氙 & $\begin{array}{l}\text { The existence of } \\
\text { representative } \\
\text { sanitation } \\
\text { infrastructure } \\
\text { facilities }\end{array}$ & $\begin{array}{l}\text { There is a separation of types of waste in each } \\
\text { trash can } \\
\text { - Trash can at public facilities } \\
\text { - There are TPS in housing that has more than } 100 \\
\text { residential units } \\
\text { - There is a waste utilization activity that can be } \\
\text { recycled }\end{array}$ \\
\hline 14 & & $\begin{array}{l}\text { The existence of } \\
\text { regional utility } \\
\text { infrastructure } \\
\text { facilities } \\
\text { (electricity, } \\
\text { water, } \\
\text { telephone/internet } \\
\text { ) }\end{array}$ & $\begin{array}{l}\text { - Regional utility facilities will be better when using } \\
\text { planting infrastructure but adapted to the class and } \\
\text { segmentation of the housing market } \\
\text { - Clean water management when using artesian } \\
\text { wells can be managed by residents with a } \\
\text { contribution system used for the maintenance and } \\
\text { prosperity of the mosque }\end{array}$ \\
\hline
\end{tabular}




\begin{tabular}{|c|c|c|c|}
\hline No & $\begin{array}{l}\text { Vari } \\
\text { able }\end{array}$ & Sub - Variable & Research Findings \\
\hline 15 & & $\begin{array}{l}\text { Presence of } \\
\text { shared space } \\
\text { (community hall, } \\
\text { sports field, } \\
\text { playground) }\end{array}$ & $\begin{array}{l}\text { - Shared space must be proportional and well- } \\
\text { integrated and support citizens' activities. } \\
\text { - Shared space can be integrated with the mosque so } \\
\text { that the center of community activities can be } \\
\text { focused at the mosque. } \\
\text { - The existence of field facilities or other public } \\
\text { facilities such as swimming pools, playgrounds } \\
\text { should be able to raise the theme according to the } \\
\text { sunnah. }\end{array}$ \\
\hline 16 & & $\begin{array}{l}\text { Existence of } \\
\text { Educational } \\
\text { facilities (Formal } \\
\text { / Informal) }\end{array}$ & $\begin{array}{l}\text { - There are informal education facilities in the form } \\
\text { of integrated Tahfidz or TPQ houses } \\
\text { - The maximum distance between formal education } \\
\text { facilities can be reached within a } 2 \mathrm{~km} \text { radius. }\end{array}$ \\
\hline 17 & & $\begin{array}{l}\text { The existence of } \\
\text { health facilities } \\
\text { (posyandu, } \\
\text { clinics, etc.) }\end{array}$ & $\begin{array}{l}\text { - The maximum distance between health facilities is } \\
\text { within a } 2 \mathrm{~km} \text { radius. } \\
\text { - In the shared space and around the mosque, it can } \\
\text { be used for Islamic gymnastics and posyandu } \\
\text { activities }\end{array}$ \\
\hline 18 & & $\begin{array}{l}\text { The existence of } \\
\text { commercial or } \\
\text { shopping } \\
\text { facilities } \\
\text { (stalls/shops) }\end{array}$ & $\begin{array}{l}\text { - There are commercial facilities for residential } \\
\text { areas that are far from the commercial center of the } \\
\text { environment } \\
\text { - The maximum distance between commercial or } \\
\text { shopping facilities can be reached within a radius } \\
\text { of } 1 \mathrm{~km} \text {. }\end{array}$ \\
\hline 19 & & $\begin{array}{l}\text { The location of } \\
\text { regional } \\
\text { infrastructure } \\
\text { facilities is easily } \\
\text { accessible and } \\
\text { user-friendly for } \\
\text { the elderly, } \\
\text { women, and } \\
\text { children. }\end{array}$ & $\begin{array}{l}\text { Regional infrastructure facilities must be easily } \\
\text { accessed with a maximum ideal distance of } 100 \text { - } \\
165 \text { meters } \\
\text { There are supporting facilities for the disabled and } \\
\text { elderly in facilities that have different heights } \\
\text { using ramps. } \\
\text { The material used is user friendly for the elderly, } \\
\text { women, and children. }\end{array}$ \\
\hline 20 & & $\begin{array}{l}\text { There are no } 3 \mathrm{D} \\
\text { ornaments/works } \\
\text { in the form of } \\
\text { animals/humans. }\end{array}$ & $\begin{array}{l}\text { - 3D ornaments and works must be in the form of } \\
\text { Islamic geometry, plants, and flowers. } \\
\text { - There are no permits of animal and human statues } \\
\text { - A better ornament design is one that contains } \\
\text { Islamic values. }\end{array}$ \\
\hline 21 & & $\begin{array}{l}\text { The existence of } \\
\text { supporting } \\
\text { vegetation area. }\end{array}$ & $\begin{array}{l}\text { Some vegetations show the characteristics of } \\
\text { Islamic housing, such as palm, bidara, and } \\
\text { vegetation which have properties according to the } \\
\text { Koran and Al-Hadith. }\end{array}$ \\
\hline
\end{tabular}

Source : Investor of Medina Residence Project Interview (2020) 


\section{CONCLUSIONS}

Based on the results of evaluations by investors and in-depth analysis qualitatively and quantitatively about the application of the concept of Islamic housing in the case study of sharia housing development Medina Residence 1 shows that in the case of Medina Residence 1 it is representative enough to show the application of the ideal Islamic residential concept (Table 4). This can be seen from all aspects examined the physical aspects of the Medina Residence housing which received a fairly good evaluation response from investors. Although there are still many things that need to be improved to improve the quality of the application of Islamic residential concepts.

\section{REFERENCES}

Amalia, z., Bambang, Pranggono (2017). Kajian Penerapan Prinsip-prinsip Perumahan Islami pada Perumahan Muslim Bukit Az Zikra. Seminar Penelitian Sivitas Akademika Unisba, 3.

Edrees, M. B. (2012). Konsep arsitektur islami sebagai solusi dalam perancangan arsitektur.

Groat, L. N. W., D. (2013). Architectural Research Methods, Wiley.

Kuntartianto, A. (2013). Upaya Membangun Masyarakat Religius (Studi Atas Pemikiran Nurcholish Madjid) Strata 1 Skripsi, UIN Sunan Kalijaga.

Miles, M. B., Huberman, A.M (2014). Qualitative Data Analysis, A Methods Sourcebook, Depok, UI-Press.

Miles, M. E. U. L., Institute (2013). Real estate development: principles and process, Washington, D.C., Urban Land Institute.

Murbaintoro, T. (2009). Model Pengembangan Hunian Vertikal Menuju Pembangunan Perumahan Berkelanjutan. Jurnal Permukiman, 4.

Poerwandari, E. K. (2009). Pendekatan Kualitatif, Depok, Lembaga Pengembangan Sarana Pengukuran dan Pendidikan Psikologi Fakultas Psikologi UI.

Sugiyono (2007). Statistika Untuk Penelitian, Bandung, CV. Alfabeta. 